\title{
Reverse Fishbone Perspective
}

After the discovery of perspective during the Renaissance, the rules of perspective became so familiar that people began to look down on earlier painters or artists from other cultures, who did not follow those rules, such as the 'Flemish Primitives', or Byzantine iconographic drawers. In this paper we recall a method for explaining the well-known regular perspective and parallel projection based on the classical Monge top view

Dirk Huylebrouck

Professor of mathematics, Faculty for Architecture, KU Leuven

Belgium and profile view. Next, we combine regular perspective and parallel projection to get Panofsky's so-called 'fishbone perspective', showing it is the logical result of an algorithmic construction. It also illustrates the analogy between the vertical fishbone method and the horizontal one. It can be combined with the above mentioned reverse perspective in which objects are drawn as if they are seen from some imaginary point behind the screen and above the observer, that is, from 'the heavens' (though the present paper argues it should rather be from a point below, from 'hell'). The algorithmic construction methods also explain why there are intermediate forms, and thus the critiques, using mainly philosophical arguments, were perhaps too unforgiving.

Keywords: descriptive geometry; fishbone perspective; oblique projection; reverse or Byzantine perspective.

\section{PERSPECTIVE AND OBLIQUE PROJECTION}

After the discovery of perspective during the Renaissance, the rules of perspective became so familiar that they became the standard for any self-respecting drawing. At present, when we see the construction for a perspective drawing we can hardly imagine it took so long for artists and mathematicians (for a long time, the study of perspective was a topic common to both art and mathematics) to (re-) discover it (see Fig. 1, 2 and 3a).

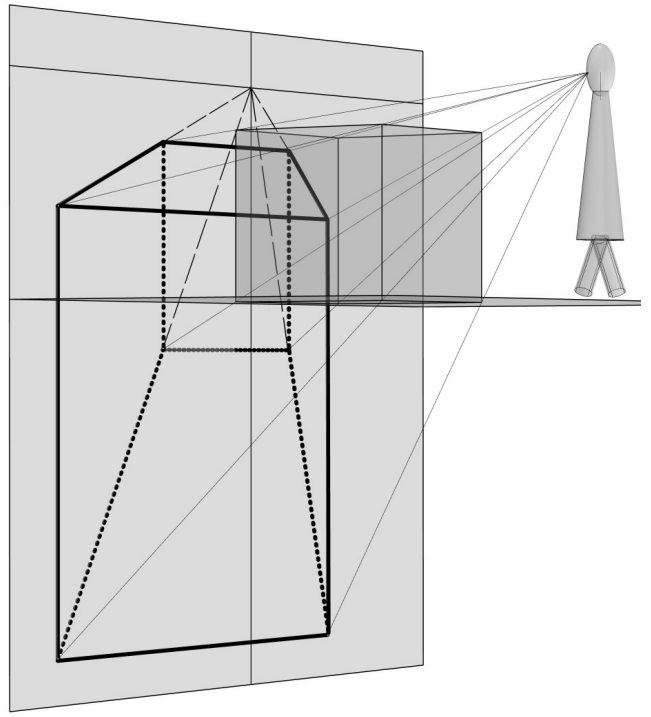

Figure 1. Traditional construction of a perspective drawing with one vanishing point: a 3D view.

Received: June 2016, Accepted: October 2016

Correspondence to: Dirk Huylebrouck

Professor of Mathematics, Faculty of Architecture,

KU Leuven, Belgium

E-mail: dirk.huylebrouck@kuleuven.be

doi:10.5937/fmet1702209H

(C) Faculty of Mechanical Engineering, Belgrade. All rights reserved

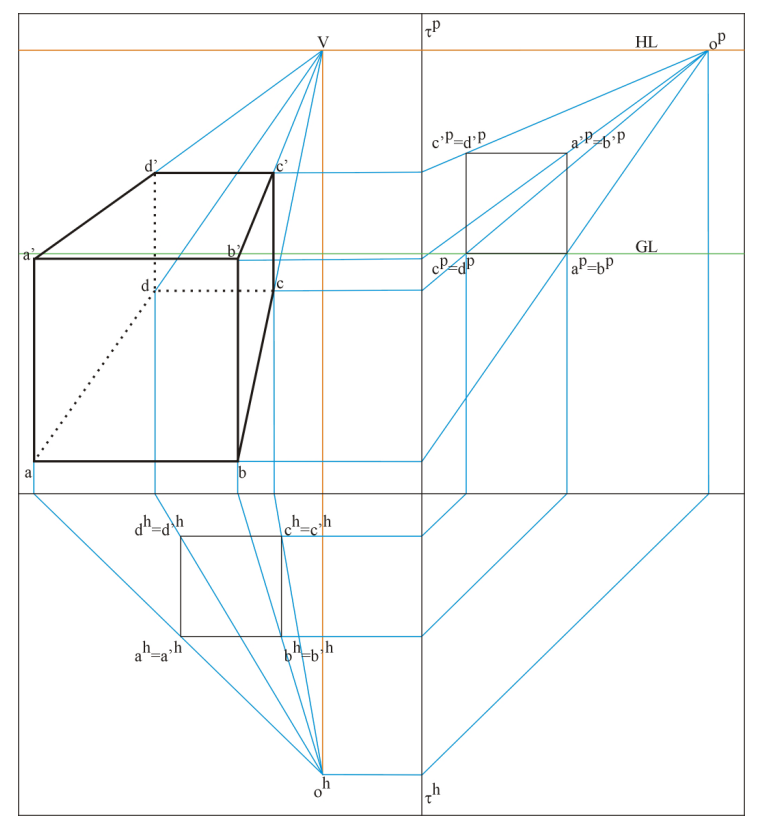

Figure 2. A similar construction using the Monge method.

Instead of using perspective using a one-point viewpoint, one can also use parallel projections. For instance, looking from a direction that makes a $19.8^{\circ}$ down with a horizontal plane and $19.8^{\circ}$ left with a profile plane, yields the so-called cavalier projection (see Fig. 3). If a cube stands on a horizontal plane, with profile and frontal faces (as in Fig. 1 and 2), the lengths of the edges of the faces in a frontal plane are of equal length in their projection, while the lengths of the edges perpendicular to the projection plane (the lines going backward) are halved. The latter make an angle of $45^{\circ}$ with the horizon and thus, following Wikipedia, this drawing method is "a simple type of technical drawing of graphical projection used for producing twodimensional images of three-dimensional objects". 


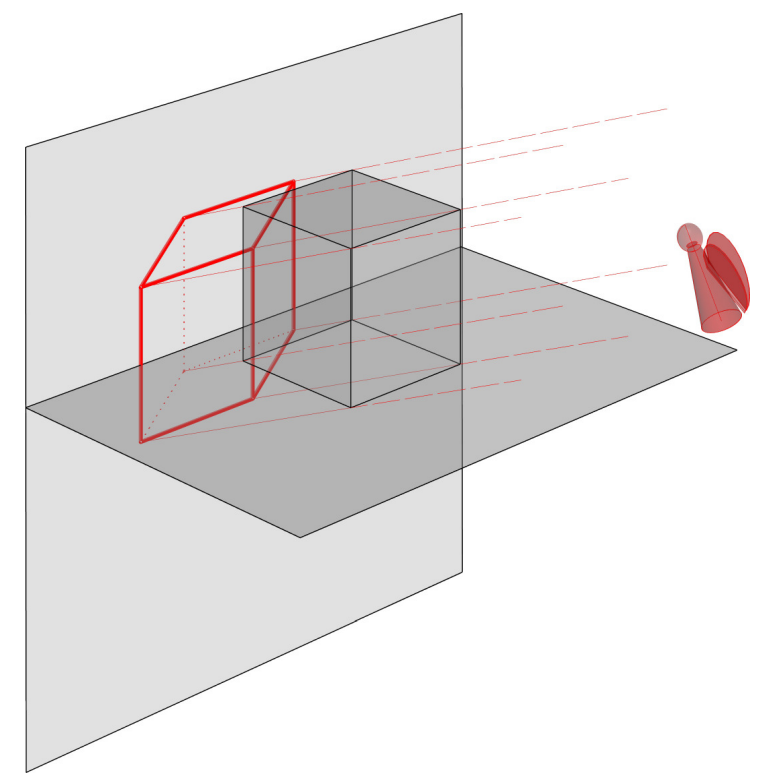

Figure 3. Cavalier construction: 3D view with an 'angle' looking with parallel lines of sight.

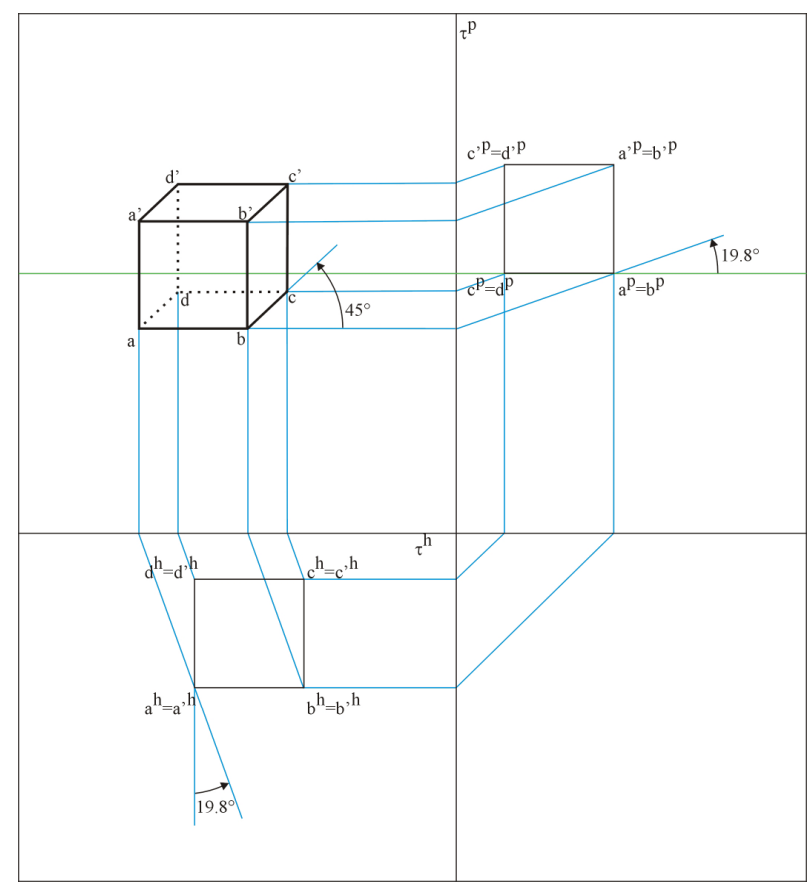

Figure 4. a similar construction using the Monge method.

Many textbooks, and Wikipedia as well, add that "the objects are not in perspective, so they do not correspond to any view of an object that can be obtained in practice, but the technique does yield somewhat convincing and useful images." This seems an overstatement to me, since one can interpret the oblique projection as a perspective with parallel sight lines, yielding vanishing points 'at infinity' in the final result. With some ingenuity, one can imagine this is how someone with dreamy eyes would observe reality, or someone 'far away', or a drugged person with 'a Rastafari look' at the world. This is why an angle was used to represent the observer in Fig. 3. Applying different angles instead of twice $19.8^{\circ}$ in the top and left view yields oblique projections that are not cavalier projections, such as an isometry or a axonometric representation. In Asia the oblique projection method was widely used in traditional drawings (see Fig. 3b).

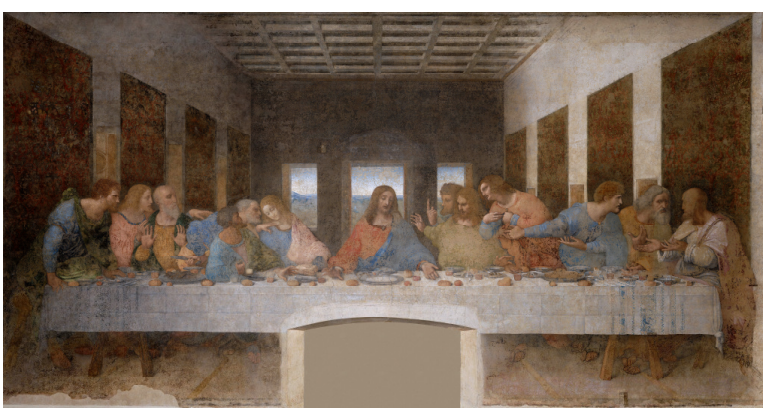

Figure 5. A classic example of a perspective drawing: Leonardo da Vinci's 'Last Supper', where Jesus overlaps the vanishing point thus stressing his central position (source: Wikimedia Commons).

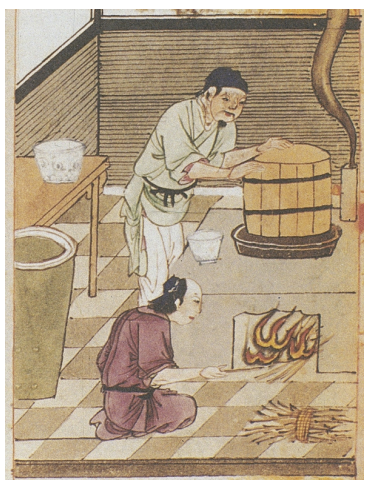

Figure 6. A classic example of a cavalier projection: a Chinese drawing (source: Wikimedia Commons).

\section{MIXING PERSPECTIVE AND OBLIQUE PROJECTION}

Classical perspective gained so much importance the masters who were skilled in using the technique began to look down on earlier painters or artists from other cultures, who did not follow those rules. For instance, the term 'Flemish Primitives' refers to the 'primitive' methods in the paintings form the Burgundian and Habsburg Netherlands during the 15th- and 16thcentury. Initially, it was on offensive term, though through time it became an honorary title for Flemish painting (see Fig. 7). Typically, parallel sight lines do not converge to a central vanishing point, but to a vanishing line. Panofsky coined the term 'fishbone perspective' and discussed the symbolic interpretation (see Fig. 8). His work was referred to over and over, but here we present a technical aspect, that is, how it can be drawn using the above classical simple techniques.

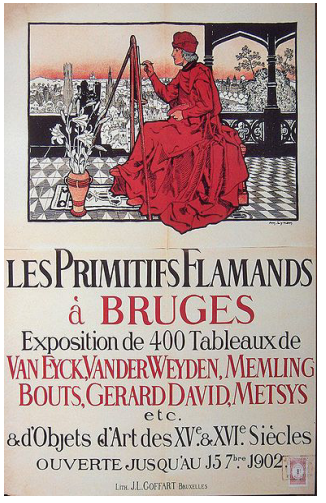

Figure 7. An exhibition from 1902 used the term 'Flemish primitives' (source: own photo). 

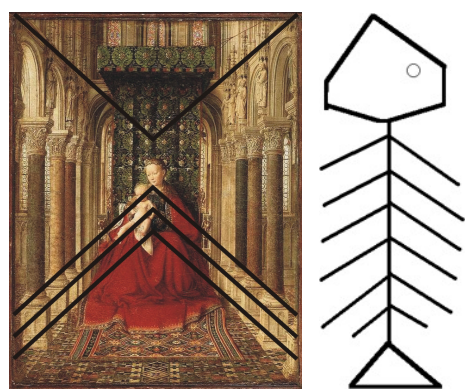

Figure 8. The Dresden Triptych (1437) by Jan Van Eyck with sight lines converging on a vertical line is in Panofsky's 'fishbone' (source: Wikimedia Commons).

Indeed, during the teaching of this topic, it struck me that by 'erroneously' both of the above method, the vertical fishbone representation occurs quite 'naturally'. It suffices to use the regular point perspective method in the top view, and the regular parallel cavalier method in the left view. In $3 \mathrm{~d}$, this corresponds to the construction of the drawing in horizontal layers. In each layer, the perspective method is correct, as in perspective method, and the layers themselves correctly use the cavalier method (see Fig. 9 and 10).

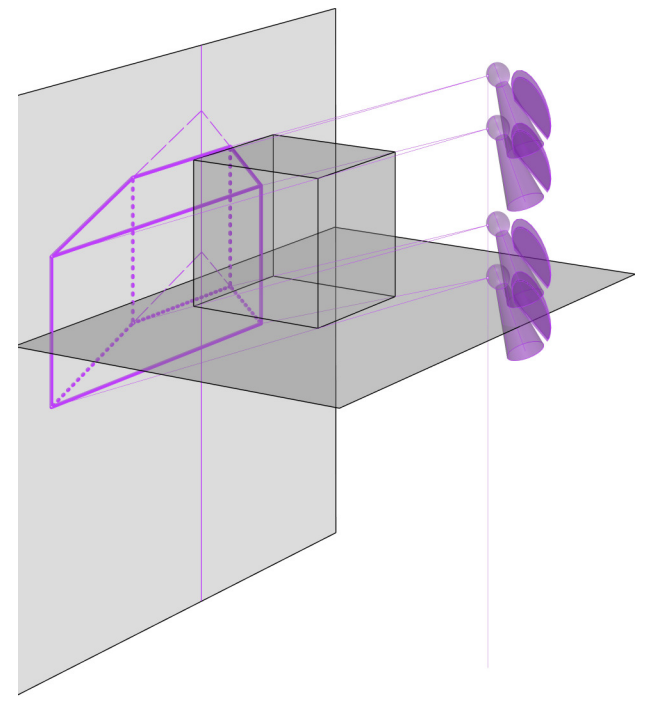

Figure 9. Vertical fishbone construction: 3D view with 'angles' looking with parallel planes of sight.

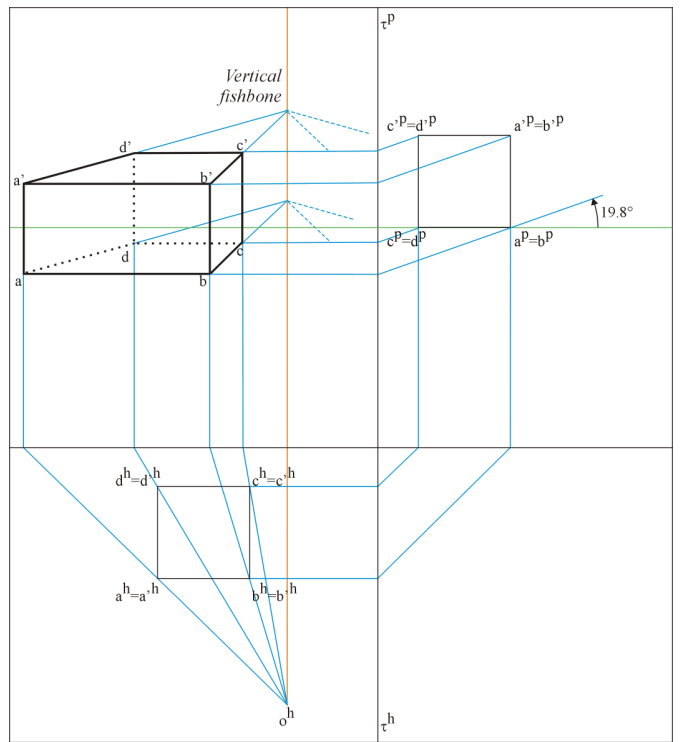

Figure 10. A similar construction using the Monge method.
To the creative descriptive geometer, this of course brings an idea to mind: why not mix the perspective method and the cavalier method differently, and use the regular point perspective method in the left view, and the regular parallel cavalier method in the top view? Indeed, this makes sense: it creates a horizontal fishbone (see Fig. 11, 12 and 13).

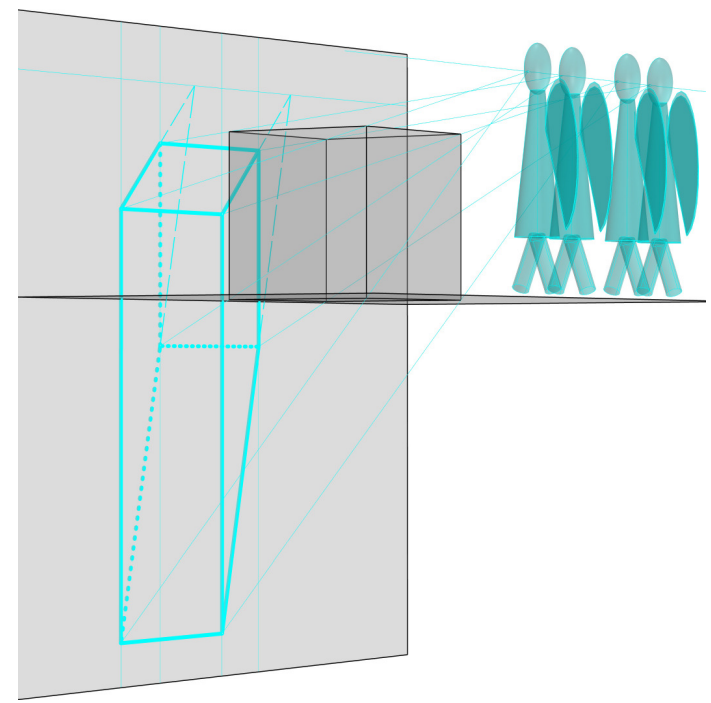

Figure 11. Horizontal fishbone construction: 3D view with observers again looking with parallel planes of sight.

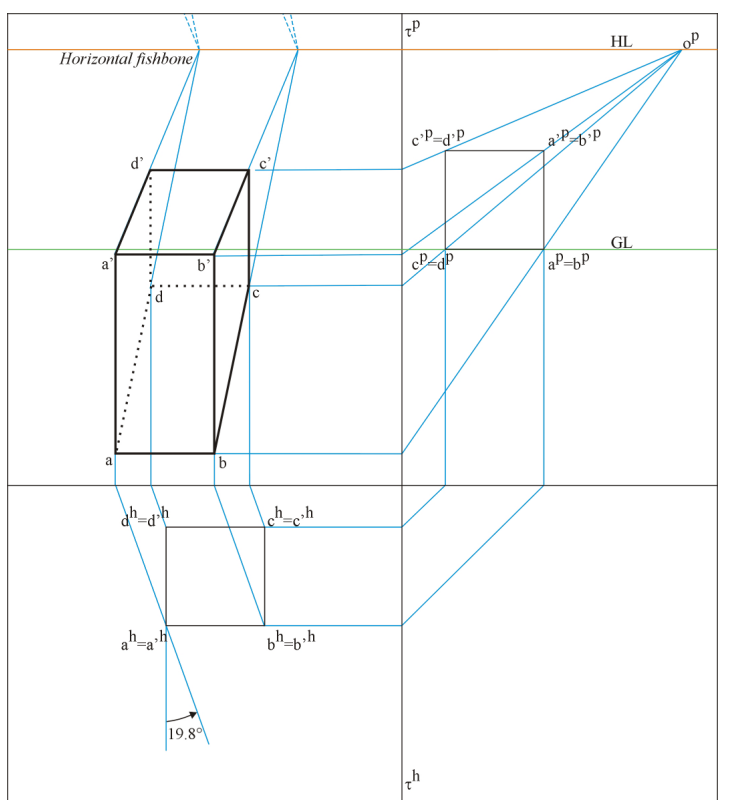

Figure 12. A similar construction using the Monge method.

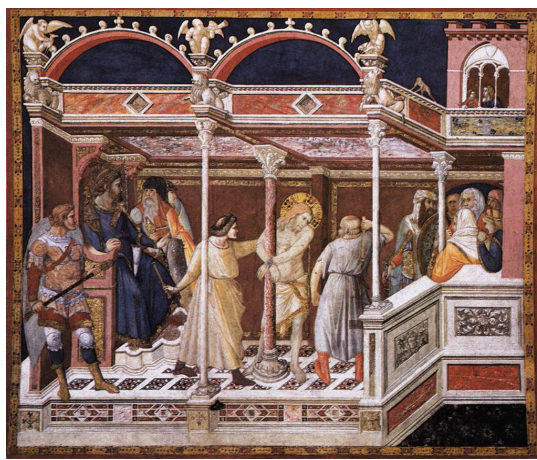

Figure 13. Example of a horizontal fishbone artwork: The Flagellation of Christ (c. 1320) by Pietro Lorenzetti (source: Wikimedia Commons). 
These constructions show that the 'fishbone perspectives' are a logical result of an algorithmic construction, which can be repeated on the computer if desired, and thus that it is more than the outcome of some loose artistic or philosophical ideas that may even seem arbitrary. It also illustrates the analogy between the vertical fishbone method and the horizontal one. For some iconographic art, however, these representations do not seem sufficient to explain them (see Fig. 14), and that will be the topic of the next section.

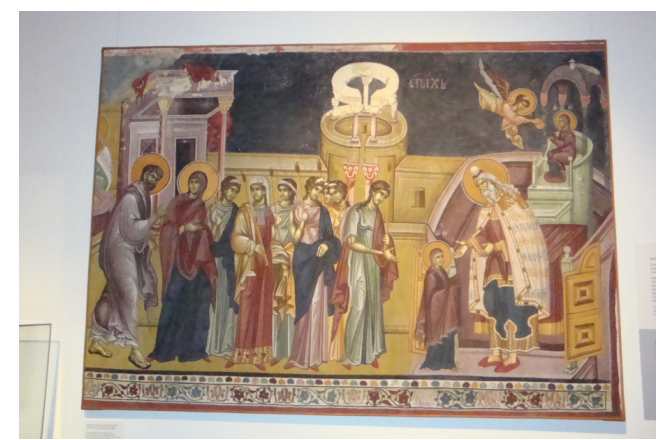

Figure 14. An introduction to the next section: the 'Presentation of the Virgin in the Temple', with an in this context appropriate angle in the above right corner (Studenica, King's Church, 1314; photo by the author).

\section{REVERSE PERSPECTIVE}

Another case with a telling name is the 'reverse' perspective in Byzantine drawings. Of course, it refers to the apparently opposite sense of the perspective lines, that seem to come towards the observer of the drawing instead of going away from him, but its name can also be interpreted as opposed to the 'regular, direct' perspective. However, from the viewpoint of the usual descriptive geometry, the method can be explained by a drawing similar to the above, but now the drawer and the observer each stand at the other side of the scene of projection. It doesn't change much to the construction itself, but the visible and hidden lines swap (see Fig. 15).
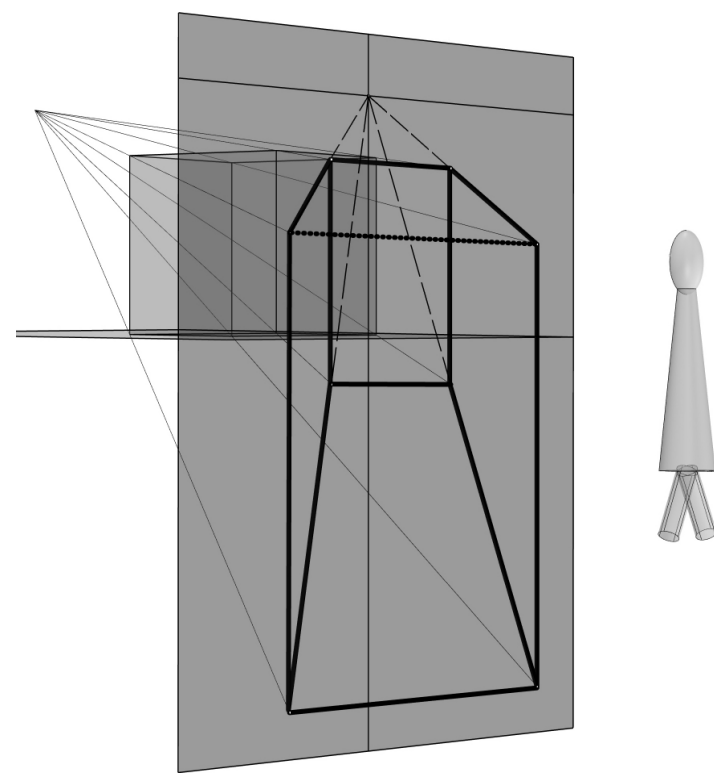

Figure 15. 3D construction for a 'reverse perspective': the drawer stands behind the screen, the observer in front.

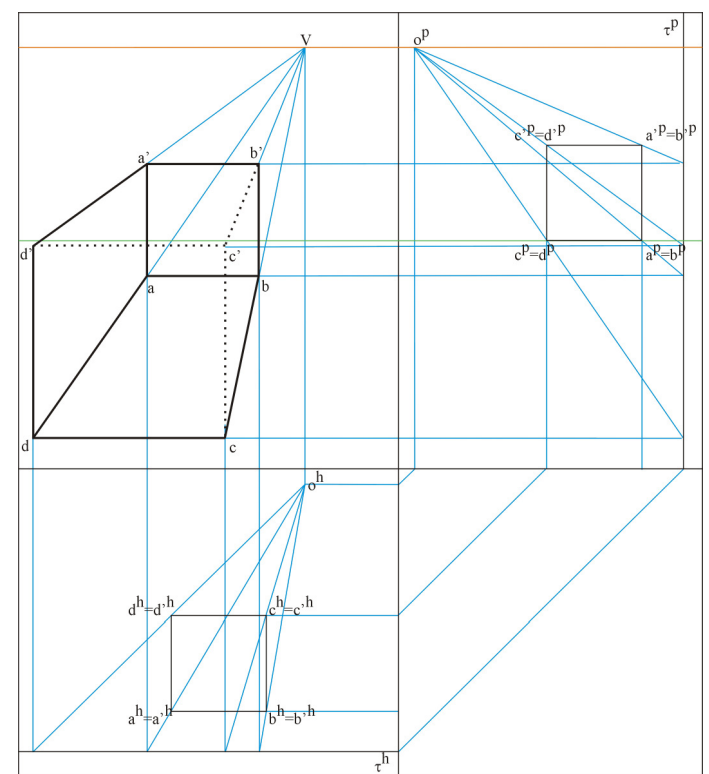

Figure 16. A similar Monge construction.

Some authors consider the reversed perspective as a drawing procedure that was used intentionally to create the impression the drawing 'comes out of the heavens'. It would increase the heavenly impression of the icons.

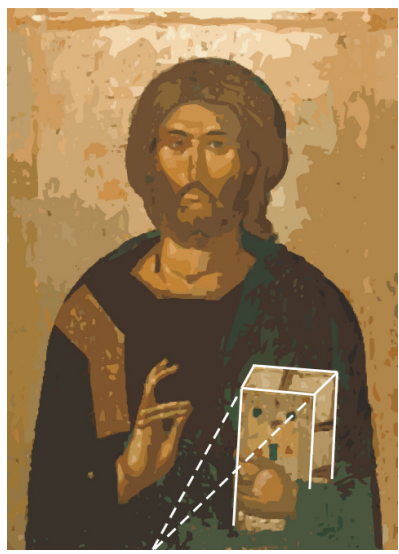

Figure 17. A 'typical' reverse perspective creating a heavenly impression (tracing by the author).

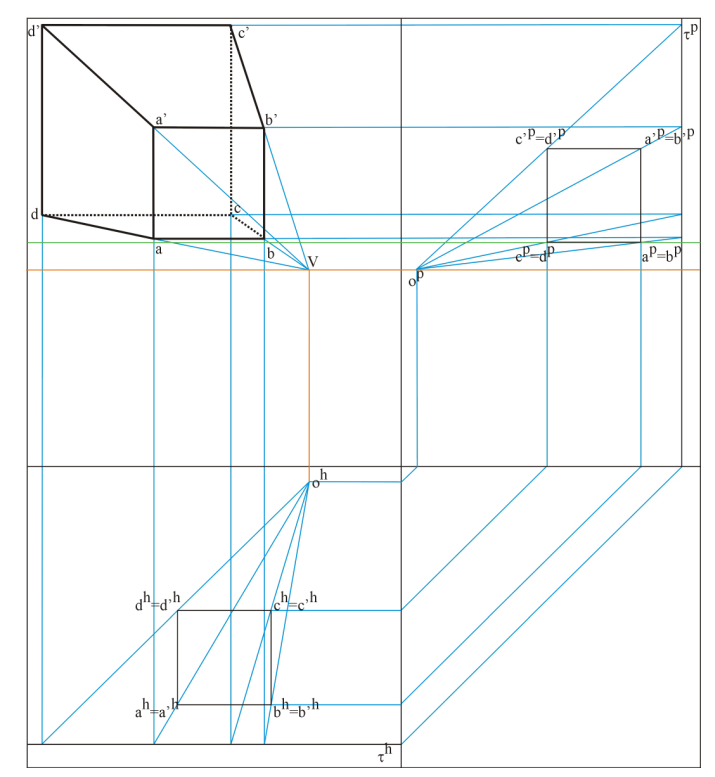

Figure 18. A reversed perspective gives a heavenly impression if the centre of projection is below the observer. 
However, when the drawer is above the cube, the observer of the reverse perspective will have the impression the cube 'comes out of hell', to stay in an analogous vocabulary (Fig. 16). In order to create a heavenly impression, the central point should be below the cube (Fig. 18).

\section{REVERSE FISHBONE PERSPECTIVE}

The creative descriptive geometer can now try to make reverse fishbone representations as well. This yields representations that could be called 'reverse horizontal or vertical fishbone' perspective. The algorithmic aspect of these construction methods also explain why there are intermediate forms. This was interpreted by some critics that the artists did not really know what they were doing and that reverse perspective is a myth, an 'a posteriori' interpretation. Perhaps this was too negative as artists could have been experimenting on aspects of different methods: a left view of one method combined with a top view of another method. Here, we used the 'modern' Monge method to explain it, but a skilled artist did not need that and could base his drawing on intuition and observation (see Fig. 20). Indeed, he could construct the image in vertical layers, moving from the left to the right while making his illustration, and drawing a 'perfect perspective' in each vertical layer.

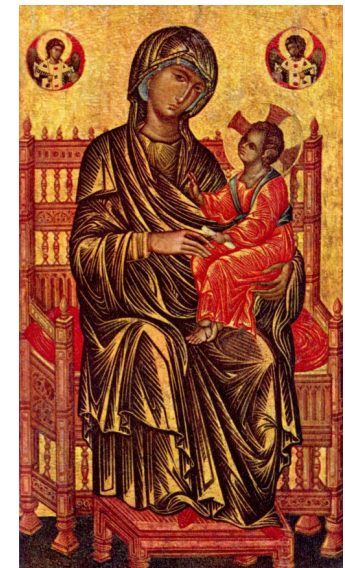

Figure 19. A reverse horizontal fishbone perspective (source: Wikimedia Commons).

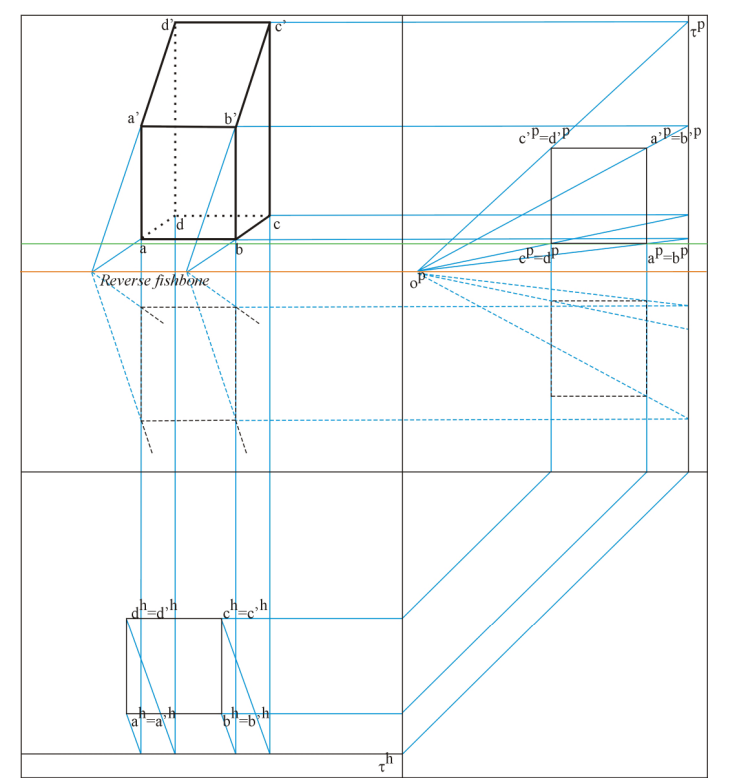

Figure 20. The Monge construction corresponding to Fig. 19.

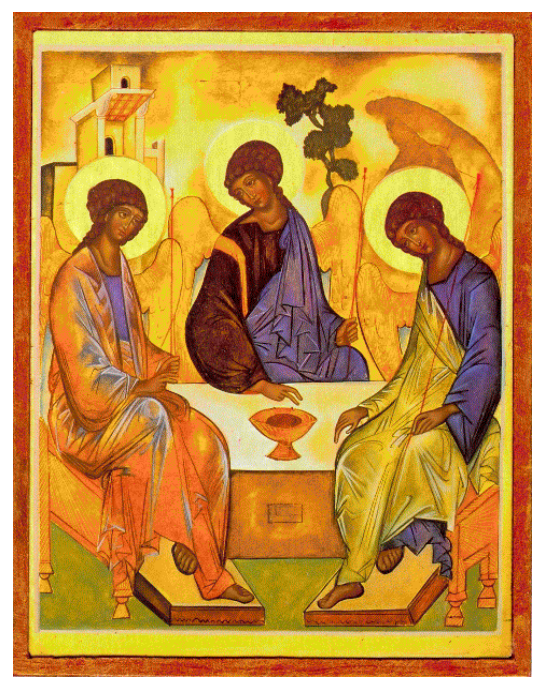

Figure 21. Work by Andrei Rublev (Russia, approx. 1360 1428) with reversed perspective, thus creating a 'heavenly impression' (source: Wikimedia Commons).

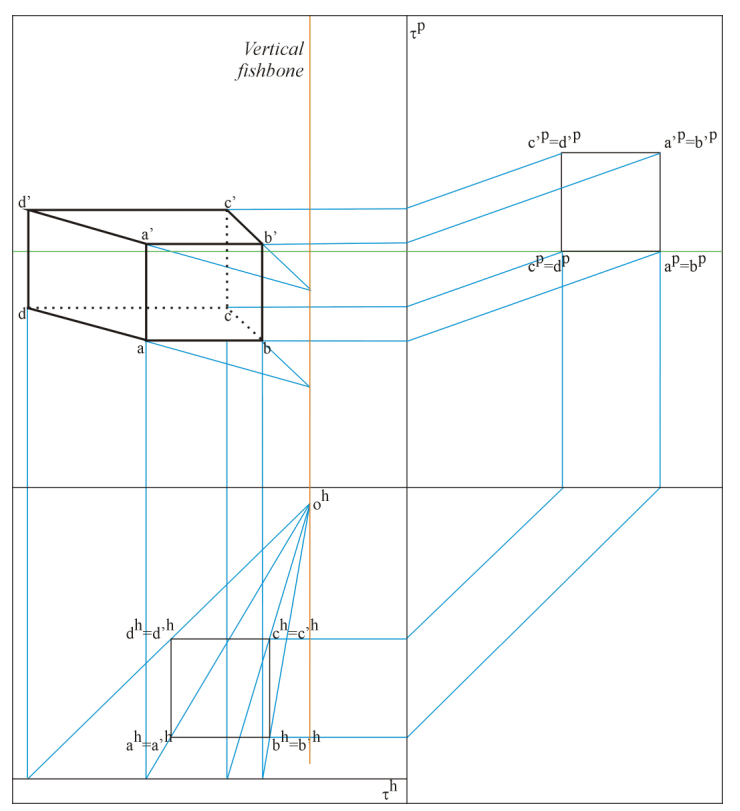

Figure 22. The reversed perspective creates a 'heavenly impression' if the observer looks downwards.

Similarly, examples of a reverse vertical fishbone can be discovered too. Again, it is a downward looking direction that creates a heavenly impression (see Fig. 21 and 22). Here it seems the artist used horizontal layers, moving up or down while making his illustration, and making a 'perfect perspective' in each horizontal layer. Thus, a part from the philosophical considerations, this Byzantine art could be inspired by logical, practical ideas as well.

\section{REFERENCES}

[1] Kirsti A.: The Geometry of an Art, The History of the Mathematical Theory of Perspective from Alberti to Monge, Springer-Verlag New York Inc. 2006.

[2] Conesa Tejada, S.: Perspectiva naturalis y perspectiva artificialis, el espacio perspectivo en la pintura primitiva italiana. Propuestas para la creación artística, $\mathrm{PhD}$ thesis at the Universitat Politècnica de València, 2011. 
[3] Panofsky, E.: Perspective as Symbolic Form, Zone Books, 1991.

[4] David (an otherwise anonymous blog): Icons and their Interpretation, Information for the objective student of Russian, Greek, and Balkan icons, https://russianicons.wordpress.com/2011/09/01/rev erse-perspective-another-icon-myth/, accessed on September 1, 2011.

\section{ОБРНУТА ПЕРСПЕКТИВА РИБЉЕ КОСТИ}

\section{Д. Хуилебрук}

После открића перспективе у периоду ренесансе њена правила су постала толико блиска људима да су почели да гледају са висине на сликаре и уметнике других култура које нису следиле правила перспективе, као што је било сликарство „фламанских примитиваца“ или византијско иконописање. У овом раду се подсећамо метода који ce користи за тумачење познате регуларне перспективе и паралелне пројекције засноване на класичном Монжовом пару хоризонталне и профилне пројекције. Затим, комбинујемо нормалну са паралелном пројекцијом да бисмо добили тзв. перспективу рибље кости Панофског, при чему показујемо да је она логичан исход алгоритамске конструкције.

Такође илуструјемо аналогију метода вертикалне са методом хоризонталне рибље кости. Она се може комбиновати са поменутом обрнутом перспективом код које се објекти цртају као да су виђени из неке имагинарне тачке иза застора и изнад посматрача, тј. са ,неба““ (иако у раду тврдимо да би то пре требало да буде из тачке одоздо, из „пакла“). Методе алгоритамске конструкције такође појашњавају разлог постојања посредних форми, па су зато критичари, користећи углавном филозофске аргументе, можда били претерано непопустљиви. 